\title{
APPLICATION OF INTERPROFESSIONAL EDUCATION MODEL ON THE COGNITIVE AND SKILL COMPETENCE IN NURSING CARE FOR CHILDREN WITH MALNUTRITION AMONG STUDENTS IN PARE, KEDIRI, EAST JAVA
}

\author{
Neny Triana, Enur Nurhayati Muchsin \\ Prodi D3 Keperawatan STIKES Karya Husada Kediri
}

\begin{abstract}
BACKGROUND: Collaboration between agencies and professionals may improve the quality of child service. Interprofessional education (IPE) is a model where two or more professions in health and social care learn together during professional training with the objective to cultivating collaborative practice in patient-centered health care. There is debate about the effectiveness of IPE in enabling collaborative practice. Research has identified some evidence of effectiveness in changing attitudes. But little is known about its effectiveness on improving cognitive and clinical skill competence. This study aimed to assess effectiveness of the application of IPE model on the cognitive and skill competence in nursing care for children with malnutrition at school and clinical practice settings.

SUBJECT AND METHODS: This was a qualitative-quantitative study using action research design, conducted in Pare, Kediri, East Java. School of Health Sciences (STIKES) Karya Husada, and Amelia Hospital, in Pare, Kediri, was selected for the application of IPE model. A sample of 16 students was selected for this study: (1) 8 from D3 Program in Nursing; (2) 4 from D3Program in Midwifery; (3) 4 D3 Program in Nutrition. The effectiveness of IPE in the two settings was assessed by in-depth interview, direct observation, and focus group discussion.
\end{abstract}

RESULTS: A. Application at Karya Husada. Cycle I: (1) Lecture, question and answer, satisfied $99.37 \%$ of the students; (2) Tutorial session satisfied $88.60 \%$ of the students; (3) Role play of actual children cases with under red line malnutrition, kwashiorkor, and obesity, proceded satisfactorily. A module was produced and reviewed by peer groups. Cycle II: Expert lecture in 3 professions (nursing, midwifery, and nutrition). 100\% of the participants understood the IPE application. B. Application at Amelia Hospital. Cycle I: Workshop in nursing care for malnourished children in IPE model, which was new to the participants. Cycle II: Direct application of IPE model on malnourished children. $98.82 \%$ of the participants understood the application of clinical practice for malnourished children.

CONCLUSION: The application of IPE model consisting of lecture, question-answer, tutorial, work-shop, and direct clinical practice, involving collaboration of 3 professions (nursing, midwifery, and nutrition) can improve the cognitive and skill competence among students.

Keywords: understanding, clinical skill, inter-professional education model, action research 